\title{
CRETACEOUS VEGETATIONAL CHANGE: A BIOMAL PERSPECTIVE
}

\author{
UPCHURCH*, Garland R., Jr., Department of Biology, Southwest Texas State
} University, San Marcos, TX 78666, U.S.A.

The Cretaceous rise of flowering plants marked an important transition in the modernization of terrestrial ecosystems. Well documented is the diversification of angiosperm pollen during the mid-Cretaceous and the migration of angiosperms from low latitudes to middle and high latitudes during the Barremian to Cenomanian. Global compilations of "species" diversity indicate a rapid rise in angiosperm diversity during the Albian to Cenomanian. This rise parallels a decline in the species diversity of archaic pteridophytes and the gymnosperm orders Cycadales, Bennettitales, Ginkgoales, Czekanowskiales, and Caytoniales. Late Cretaceous floras show more gradual trends in species diversity than mid-Cretaceous floras.

Megafloral reconstructions of vegetation and climate for North America and other continents indicate warm temperatures in coastal regions of middle to high latitudes. Cretaceous biomes, however, often cannot be compared closely with Recent biomes. During much of the Cretaceous, conifers and other gymnosperms shared dominance with angiosperms in tropical and subtropical vegetation, unlike the Recent. During the Late Cretaceous, tropical rainforest was areally restricted. The few known leaf megafloras from equatorial regions indicate subhumid, rather than rainforest, conditions. Desert and semi-desert were widespread at lower latitudes and are documented by the occurrence of evaporite minerals in China, Africa, Spain, Mexico, and South America. Mid-latitude vegetation consisted of open-canopy broadleaved and coniferous evergreen woodlands that existed under subhumid conditions and low seasonality. High-latitude vegetation of the Northern Hemisphere consisted of coniferous and broadleaved deciduous forest, rather than boreal forest and tundra. High-latitude vegetation from coastal regions of the Southern Hemisphere consisted of evergreen conifers and angiosperms. Rainforest conditions appear to have been largely restricted to polar latitudes.

Data on relative abundance, though often incomplete, indicate that angiosperms became ecologically important in tropical to warm subtropical broadleaved evergreen forests and woodlands by the Cenomanian. However, their rise to dominance took longer in other biomes. Conifers formed an important component of many Late Cretaceous biomes, and the persistence of archaic gymnosperms was strongly influenced by climate. Deciduous Ginkgoales, Czekanowskiales, Bennettitales, and Caytoniales are rare to absent in Late Cretaceous megafloras from warm subtropical to tropical climates, but they persist in megafloras from cooler climates. Archaic conifers such as Frenelopsis occur in megafloras representing low-latitude desert and semidesert, but they are generally absent in more humid assemblages. Within mid-latitude broadleaved and coniferous evergreen woodland from North America, conifers show evidence for co-dominance with angiosperms into the early Maastrichtian. However, this co-dominance appears to have ended by latest Maastrichtian, which implies that vegetational reorganization occurred during the last few million years of the Cretaceous in North America. 